\title{
Comparative Antimicrobial Study of Ethanolic Extract of Leaf and Rhizome of Curcuma longa Linn
}

\author{
Nikhil Singh*, Sangeeta Gupta, Vaibhav Rathore
}

\begin{abstract}
Introduction: Curcuma longa L., botanically related to ginger belongs to the Zingiberaceae family. It is extensively used in Ayurveda, Unani and Siddha medicine as a home remedy for various diseases. Aim: The present study is to compare the antimicrobial activity of the ethanolic extracts from rhizome and leaf of Curcuma longa Linn. Method: In vitro disc diffusion method and serial dilution method has been used to determine the antimicrobial potency against various bacterial pathogens such as Klebsiella pneumoniae Pseudomonas aeruginosa, Staphylococcus aureus and Bacillus subtilis by comparing the zone of inhibition shown by both the test extracts at different concentration $(25 \mathrm{mg} / \mathrm{ml}, 50 \mathrm{mg} / \mathrm{ml}, 100 \mathrm{mg} / \mathrm{ml}, 150 \mathrm{mg} / \mathrm{ml}, 200 \mathrm{mg} / \mathrm{ml}, 250 \mathrm{mg} / \mathrm{ml}, 300 \mathrm{mg} / \mathrm{ml}$ ) and there MIC value has been evaluated. Ethanol and Ampicillin were used as negative and positive control for the study. Result: The leaf and rhizome extract showed maximum zone of inhibition at $300 \mathrm{mg} / \mathrm{ml}$ concentration, which was about $7.6 \mathrm{~mm}$ and $8 \mathrm{~mm}$ on the bacterial strain Pseudomonas aeruginosa and least effectiveness for other bacterial strain such as Staphylococcus aureus and Bacillus subtilis. The recorded MIC value was at 6.25 $\mathrm{mg} / \mathrm{ml}$ which showed $3.991 \%$ inhibition for rhizome extract and 3.129\% inhibition for leaf extract. Conclusion: The rhizome extract was found to be more potent antimicrobial agent than the leaf extract and can be used in future studies.
\end{abstract}

Key words: Curcuma longa L, Minimum inhibitory concentration, antimicrobial agent, Bacterial stain, Antibacterial activity, Turmeric.

\section{INTRODUCTION}

Now-a-days multiple drug resistance has developed due to the indiscriminate use of commercial antimicrobial drugs commonly used in the treatment of infectious diseases. ${ }^{1,2}$ In addition to this problem, antibiotics are sometimes associated with adverse effects on the host including hypersensitivity, immunesuppression and allergic reactions. ${ }^{3}$ Because of the side effects and the resistance that pathogenic microorganisms build against antibiotics, recently much attention has been paid to extracts and biologically active compounds isolated from plant species used in herbal medicine. ${ }^{4}$ However, the potential of higher plants as sources for new drugs is still largely unexplored. India is the largest producer of medicinal herbs and appropriately called the botanical garden of the world. ${ }^{5}$ Coincidentally, the last decade has also witnessed increasing intensive studies on extracts and biologically active compounds isolated from plant species used for natural therapies or herbal medicine ${ }^{6}$ Therefore, there is a need to develop alternative antimicrobial drugs for the treatment of infectious diseases from medicinal plants. ${ }^{7,8}$ Several screening studies have been carried out in different parts of the world. There are several reports on the antimicrobial activity of different herbal extracts in different regions of the worlds. ${ }^{9,10}$

Turmeric (Curcuma longa L.) is a medicinal plant extensively used in Ayurveda, Unani and Siddha medicine as home remedy for various diseases. Cur- cuma longa $L$., botanically related to ginger belongs to the Zingiberaceae family. ${ }^{11}$ It is a perennial plant having a short stem with large oblong leaves and bears ovate, fusiform or oblong rhizomes, which are often branched and brownish-yellow in colour. Turmeric rhizome is used as a food additive (spice), preservative and colouring agent and is considered as auspicious and is a part of religious rituals. ${ }^{12}$ The compounds showing yellow colour are three curcuminoid compounds; curcumin, demethoxycurcumin and bisdemethoxycurcumin. Curcumin a yellow bioactive pigment, is the major component of turmeric. It has been shown that curcumin have a wide spectrum of biological activities. ${ }^{13}$ The extracts of turmeric rhizome has recently been used as an insect repellent ,anti-bacterial, ${ }^{14}$ antidiabetic, ${ }^{15}$ antioxidant, ${ }^{16,17}$ anti-inflammatory, ${ }^{18,19}$ anticancer, ${ }^{20}$ antiallergic, ${ }^{21}$ antiprotozoal ${ }^{22}$ and wound healing activity. ${ }^{23}$ The main objectives of the present study were to evaluate and compare the antimicrobial activity of the extracts from rhizome and leaf of Curcuma longa Linn against various bacterial pathogens.

\section{MATERIALS AND METHODS}

\section{Preparation of plant material and extracts}

Fresh leaves and rhizomes of Curcuma longa were collected from the local area and the sample was identified by Botanist. from G.B Pant University, Pantnagar, Moradabad. Fresh leaves and rhizome
Cite this Article: Singh N, Sangeeta G, Rathore V. Comparative Antimicrobial Study of Ethanolic Extract of Leaf and Rhizome of Curcuma longa Linn. Pharmacogn J. 2017;9(2): 208-12. 
were cleaned and cut into small pieces and air dried for 2 days. The dried sample was again dried in a hot air oven at $50^{\circ} \mathrm{C}$ for $24 \mathrm{hrs}$, then pulverized by a mechanical grinder and passed through a 20 mesh sieve. The dried powdered was extracted with ethanol using a Soxhlet apparatus. The extraction was carried out for $24 \mathrm{hrs}$ at room temperature. And the extracts were filtered and concentrated at $35^{\circ} \mathrm{C}$ under reduced pressure and stored at $4^{\circ} \mathrm{C}$ for further experiment.

\section{Test microorganism}

The test organisms were clinical isolates from the stock culture acquired from the Institute of Microbial Technology (IMTech), Chandigarh, India. Following four bacterial strains were used in the present study. Gram positive bacteria- Klebsiella pneumoniae (MTCC 4032), Pseudomonas aeruginosa (MTCC 6458) \& Gram negative bacteria, Staphylococcus aureus (MTCC 3160), Bacillus subtilis (MTCC 2757). Each of these microorganisms was subculture unto nutrient broth to test for viability and subsequently on nutrient agar slants and kept at $4^{\circ} \mathrm{C}$ prior to susceptibility testing

\section{Antimicrobial activity}

In-vitro antimicrobial screening was generally performed by paper disc diffusion method for the primary selection of the compound as therapeutic agent. ${ }^{24}$ The antimicrobial activity was performed on the ethanol extract of the rhizome and leaf of Curcuma longa. Activity was performed against four pathogenic bacteria like Bacillus subtilis, Staphylococcus aureus, Pseudomonas aeruginosa and Klebsiella pneumoniae (Two Gram positive and two Gram negative bacteria). Sterile discs (6 mm diameter) made of Whatman filter paper were impregnated with $20 \mu \mathrm{l}$ of different concentration of both the test extract $(25 \mathrm{mg} / \mathrm{ml}, 50 \mathrm{mg} / \mathrm{ml}$, $100 \mathrm{mg} / \mathrm{ml}, 150 \mathrm{mg} / \mathrm{ml}, 200 \mathrm{mg} / \mathrm{ml}, 250 \mathrm{mg} / \mathrm{ml}, 300 \mathrm{mg} / \mathrm{ml})$ and air dried to eliminate residual solvent and then was placed on the agar media In addition to these disc loaded with ethanol and disc loaded with Ampicillin were used as negative and positive control. Plates were then incubated in BOD incubator at $37^{\circ} \mathrm{C}$ for $24 \mathrm{~h}$. After incubation both the plates were observed for zones of inhibition, and their diameter were measured including the diameter of the disc.

\section{Determination of Minimum inhibitory concentration (MIC)}

Minimum inhibitory concentrations (MIC) of the ethanol extract of rhizome and leaf of Curcuma longa were determined by Serial dilution method. ${ }^{25}$ Nutrient broth media were prepared and $5 \mathrm{ml}$ of media is taken in each of the test tube. Ethanol extract of leaf and rhizome is prepared of different concentration $(6.25 \mathrm{mg} / \mathrm{ml}, 12.50 \mathrm{mg} / \mathrm{ml}, 25 \mathrm{mg} / \mathrm{ml}, 50 \mathrm{mg} /$ $\mathrm{ml}, 100 \mathrm{mg} / \mathrm{ml}$ and $200 \mathrm{mg} / \mathrm{ml}$ ). Freshly grown bacterial strains of Pseudomonas aeruginosa is inoculated in broth media and grown at $37^{\circ} \mathrm{C}$ for 18 hrs. Each tube was inoculated with different concentration of both the extracts prepared at different concentration. All the tubes were incubated at $37^{\circ} \mathrm{C}$ on a shaker with $140 \mathrm{rpm}$ for $24 \mathrm{~h}$. Presence of turbidity denoted presence of microorganism in the test tube after the period of incubation, whereas the complete absence of any turbidity indicates complete inhibition of microbial growth. The test tube with the lowest dilution with no detectable growth by visual inspection was considered the MIC. After incubation, the bacterial growth was measured at 660 $\mathrm{nm}$. The $\%$ of inhibition was calculated by using the formula below:

$\%$ Inhibition $=$ OD of culture with sample/ OD of culture without sample $x 100$

\section{RESULT AND DISCUSSION}

In the present investigation, comparison of the ethanol leaf extract and rhizome extract were evaluated for their antibacterial properties. It has been found that various ethanobotanical study of Curcuma longa revealed effective antibacterial properties. ${ }^{26}$ Various researcher have also worked in exploring the antimicrobial properties present in the various parts of the plants such as leaf and rhizome extract of Curcuma longa. In the present investigation the ethanolic plant extract of Curcuma longa was tested against the four pathogenic bacterial strains viz. Klebsiella pneumonia, Staphylococcus aureus, Pseudomonas aeruginosa and Bacillus subtilis. The antibacterial efficacy of the extract of Curcuma longa (L.) leaves and rhizomes was quantitatively assessed on basis of inhibition zone and MIC (minimum inhibitory concentration). The zone of inhibition by disc diffusion method shown by both the ethanolic leaf and rhizome extract on various concentration are given below in Table 1 and 2 .

The ethanol extract of leaf and rhizomes show maximum zone of inhibition at concentration $(300 \mathrm{mg} / \mathrm{ml})$ on the bacterial strain Bacillus subtilis. The leaf ethanolic extract was more effective showing $7.6 \mathrm{~mm}$ zone of inhibition on Bacillus subtilis at concentration $300 \mathrm{mg} / \mathrm{ml}$ while it was about $7.0 \mathrm{~mm}$ zone of inhibition for the pathogen Pseudomonas aeruginosa for the same concentration when compared with the standard and was less effective While the Ethanolic extract of rhizome show maximum zone of inhibition of about $8.0 \mathrm{~mm}$ at concentration $300 \mathrm{mg} / \mathrm{ml}$ on the same bacterial stain Bacillus subtilis while less effective for the pathogens Staphylococcus aureus showing $7.0 \mathrm{~mm}$ zone of inhibition when compared with the standard drug at the same concentration. This can be further seen that the present study result is satisfactory by investigating various similar works such as the alcoholic leaf extract of Curcuma longa had shown effective antibacterial effect on various strains with showing maximum zone of inhibition on the Bacillus bacterial strain..$^{27,28}$ And the rhizome extract of Curcuma longa was reported to show effective antibacterial activity in the study of various medicinal herbs showing antimicrobial properties in which Curcuma longa rhizome is taken as one of the herb. ${ }^{29}$ It has been also reported that curcuminoids isolated from the rhizomes of Curcuma longa shows potent antimicrobial activity against B. subtilis, E. coli, S. auresus and P. mirabilis, whereas it showed moderate activity against K. pneumonia, Enterobacter aerogenes and Pseudomonas aeruginosa. ${ }^{30}$

The MIC value reported on ethanolic extract of leaf and rhizomes of Curcuma longa was performed on bacterial strain Pseudomonas aeruginosa on which antimicrobial activity was found to be more potent. The percentage inhibition at various concentration $(200,100,50,25,12.5$ and $6.5 \mathrm{mg} / \mathrm{ml}$ ) was reported for both the extract is given in Table 3 below.

The MIC value is the lowest concentration that completely inhibited the growth of microorganisms grown aseptically. The percentage inhibition reported at various concentrations on the bacterial strain Pseudomonas aeruginosa with minimum concentration of about $6.25 \mathrm{mg} / \mathrm{ml}$ obtain by various fold of dilution. The MIC value for leaf and rhizome ethanolic extract shows very less variation and was found to be $3.129 \%$ and $3.991 \%$ whereas the percent inhibition at highest concentration 200mg/ $\mathrm{ml}$ was found to be $93.125 \%$ for rhizome extract and $91.058 \%$ for leaf extract. The rhizome show more potent antimicrobial potency when compared with the leaf extract as observed in the Figure 1. The various phytochemical study on the leaf and rhizome of the plant Curcuma longa revealed the presence of various active constituents such as alkaloids, tannins, flavonoids, glycosides and saponins seen in both the leaf and the rhizome extract. ${ }^{31,32}$ It has been also reported that the alkaloids and flavonoids are the responsible compounds for antibacterial activity in various plants. ${ }^{33}$ It can also be said that the various components which are present both in the rhizomes and the leaf of the plant Curcuma longa is responsible for the antibacterial activity against pathogens. According to the various research it has been concluded that the leaf and the rhizome show the presence of active constituents Curcuminoids showing various bands of Curcumin, bisdemethoxycurcumin and demethoxycurcumin 
Table1: Zone of inhibition shown by Ethanolic extract of leaves of Curcuma longa on different bacterial strain

\begin{tabular}{cccccccccccc}
\hline \multirow{2}{*}{$\begin{array}{c}\text { Pathogens } \\
\text { Extract dose }\end{array}$} & \multicolumn{8}{c}{ Zone of Inhibition $(\mathrm{mm})$ at different concentration } \\
\cline { 2 - 10 } & 25 & 50 & 100 & 150 & 200 & 250 & 300 & $\begin{array}{c}\text { Positive } \\
\text { control }\end{array}$ & $\begin{array}{c}\text { Negative } \\
\text { control }\end{array}$ \\
\hline $\begin{array}{c}\text { Bacillus subtilis } \\
\text { Klebsiella }\end{array}$ & 6.2 & 6.2 & 6.3 & 6.3 & 7.0 & 7.0 & 8 & 8.0 & Nil \\
$\begin{array}{c}\text { Pneumonia } \\
\text { Staphylococcus aureus }\end{array}$ & 6.1 & 6.1 & 6.2 & 6.2 & 6.4 & 6.7 & 6.8 & 7.0 & Nil & Nil \\
Pseudomonas aeruginosa & Nil & Nil & Nil & Nil & Nil & Nil & Nil & 9.0 & Nil \\
\hline
\end{tabular}

Table 2: Zone of inhibition shown by Ethanolic extract of rhizomes of Curcuma longa on different bacterial strain

\begin{tabular}{ccccccccccc} 
Pathogens & \multicolumn{8}{c}{ Zone of Inhibition $(\mathrm{mm})$ at different concentration } \\
\cline { 2 - 10 } Extract dose & 25 & 50 & 100 & 150 & 200 & 250 & 300 & $\begin{array}{c}\text { Positive } \\
\text { control }\end{array}$ & $\begin{array}{c}\text { Negative } \\
\text { control }\end{array}$ \\
\hline Bacillus subtilis & 6.4 & 6.4 & 6.4 & 6.4 & 6.4 & 7.0 & 7.5 & 9.0 & Nil \\
KlebsiellaPneumonia & Nil & Nil & Nil & Nil & Nil & 6.5 & 6.5 & 7.5 & Nil \\
Staphylococcus aureus & 6.1 & 6.2 & 6.3 & 6.3 & 6.7 & 6.7 & 7.0 & $1 \mathrm{~cm}$ & Nil \\
Pseudomonas aeruginosa & 6.1 & 6.1 & 6.1 & 6.1 & 6.2 & 6.2 & 6.6 & 9 & Nil \\
\hline
\end{tabular}

Table 3: MIC value for ethanolic extract of rhizomes and leaf of Curcuma longa at various concentrations on the bacterial strain Pseudomonas aeruginosa

\begin{tabular}{cccc}
\hline \multirow{2}{*}{ S.No } & \multirow{2}{*}{$\begin{array}{c}\text { Concentration of extract }(\mathrm{mg} / \\
\mathrm{ml})\end{array}$} & \multicolumn{2}{c}{ Bacterial Percentage Inhibition } \\
\cline { 3 - 4 } & Control & Ethanolic rhizome extract & Ethanolic leaf extract \\
\hline 1 & 200 & 93.125 & 0 \\
2 & 100 & 69.812 & 91.058 \\
3 & 50 & 67.239 & 69.746 \\
4 & 25 & 43.123 & 66.998 \\
5 & 12.5 & 10.012 & 42.399 \\
6 & 6.25 & 3.991 & 10.432 \\
7 & & & 3.129 \\
\hline
\end{tabular}

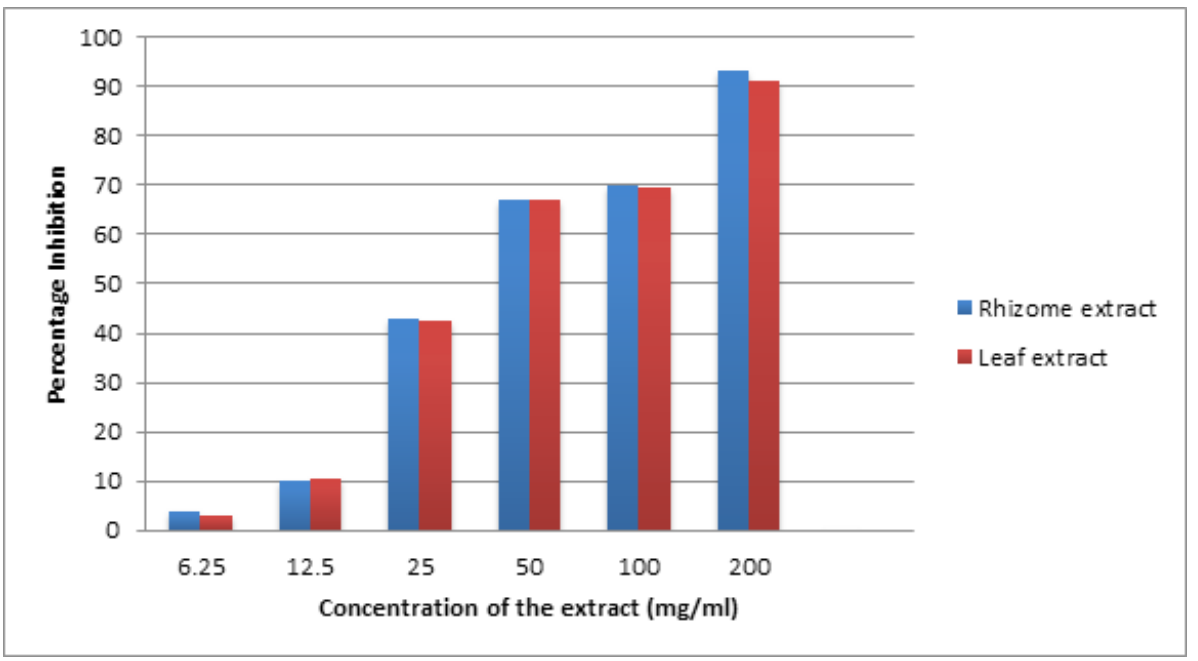

Figure 1:Graphical representation of percentage inhibition of both the extract of Curcuma longa at various concentration of the extract on Pathogen Pseudomonas aeruginosa 
in the isolation and characterization of curcuminoids by various techniques. ${ }^{30}$ The active constituents present in the Curcuma longa leaf and rhizome leads to plasmolysis, cell disruption and death of the cell wall of the specific pathogen as seen in the evaluation of antimicrobial properties in Curcuma longa rhizome extract against Staphylococcus aureus strain by electron microscopy. ${ }^{32}$

\section{CONCLUSION}

In this study, the comparative efficiency of rhizome and leaf extract of the crude drug Curcuma longa Linn were evaluated for its microbial inhibitory effect on various pathogenic bacterial strains such as Klebsiella pneumonia, Staphylococcus aureus, Pseudomonas aeruginosa and Bacillus subtilis was observed. Both the extract show potent antimicrobial agent but not on all the bacterial strains but on specific bacterial stain such as Pseudomonas aeruginosa and Bacillus subtilis show effective inhibitory result. If we compare the antimicrobial activity of both the ethanolic extract from leaf as well as from the rhizome. The rhizome extract found to be more potent in its activity than the leaf extract.

\section{ACKNOWLEDGEMENT}

I would like to express my heartful thanks of gratitude to Dr Atul Kumar, Head of Department, Plant Physiology, G. B Pant University, Pantnagar, Moradabad for his valuable support in authentication of the plant drug for the further study. I would also like to thanks Head of Department MET Faculty of Pharmacy, Moradabad for providing respective Bacterial stains and laboratory support for the conduction of the Research work.

\section{REFERENCES}

1. Davis J. Inactivation of the antibiotics and the dissemination of resistance genes. Science. 1994;264(5157):375-82. https://doi.org/10.1126/science.8153624.

2. Service R.F. Antibiotics that resist resistance. Science. 1995;270(5237):724-7. https://doi.org/10.1126/science.270.5237.724.

3. Ahamad I, Mehmood Z, Mohammad F. Screening of some Indian medicinal plants for their antimicrobial properties. J.Ethnopharmacol. 1988;62(2):183-93. https://doi.org/10.1016/S0378-8741(98)00055-5

4. Essawi T, Srour M. Screening of some Palestinian medicinal plants for antibacterial activity, J.Ethnopharmacol. 2000;70(3):343-9. https://doi.org/10.1016/ S0378-8741(99)00187-7.

5. Ahmedulla M, Nayar M P. Red Data Book of Indian Plants, Botanical Survey of India, Calcutta. 1994

6. Rıos J, Recio M. Medicinal plants and antimicrobial activity. J. Ethnopharmacol. 2005;100:80-4. https://doi.org/10.1016/j.jep.2005.04.025 PMid:15964727.

7. Clark A.M. Natural products as resource for new drugs. Phar Res. 1996;13(8):1133-41. https://doi.org/10.1023/A:1016091631721.

8. Cordell G.A. Biodiversity and drug discovery a symbiotic relationship. Phytochemistry. 2000;55(6):463-80. https://doi.org/10.1016/S0031-9422(00)00230-2.

9. Nair R, Chanda S.V. Antibacterial activity of some medicinal plants of Saurashtra region. J Tissue Res. 2000;4(1):117-20.

10. Nair R, Kalariya T, Chand S. Antibacterial activity of some selected Indian medicinal flora. Turk J Bio. 2000;29:41-7.

11. Hitesh K Dhamija,Ankit S Chauhan. Der Pharmacia Sinica. 2011;2(3):51-9.

12. Lotempio MM, Verma MS, Steel HL, Ramamurthy B, Ohen AN, Wary MB. Clin Cancer. Res. 2005;11:6994-7002. https://doi.org/10.1158/1078-0432.CCR-050301 PMid:16203793.
13. Menon VP, Sudheer AR. Antioxidant and anti-inflammatory properties of curcumin, Adv Eep Med Biol 2007;595:105-25. https://doi.org/10.1007/978-0-38746401-5_3 PMid:17569207.

14. Mohammadi K, Thompson KH, Patrick BO, Storr T, Martins C, Polishchuk E et al. Synthesis and characterization of dual function vanadyl, gallium and indium curcumin complexes for medicinal applications. J Inorg. Biochem. 2005;99(11):221725. https://doi.org/10.1016/j.jinorgbio.2005.08.001 PMid:16171869.

15. Hatcher H, Planalp R, Cho J, Torti FM, Torti SV. Curcumin: from ancient medicine to current clinical trials. Cell Mol Life Sci. 2005;65(11):1631-52. https://doi. org/10.1007/s00018-008-7452-4 PMid:18324353 PMCid:PMC4686230.

16. Rudrappa T, Bais HP. Curcumin, a known phenolic from Curcuma longa, attenuates the virulence of Pseudomonas aeruginosa PAO1 in whole plant and animal pathogenicity models. J Agric and Food Chem. 2008;56(6):1955-62. https://doi. org/10.1021/jf072591j PMid:18284200.

17. Mohamed AE, Abdel-Aziz AF, El-Sherbiny EM, Mors RM. Anti-diabetic effect of Aloe vera juice and evaluation of thyroid function in female diabetic rats. Bio Sci Res. 2009;6;28-34.

18. Punithavathi D, Venkatesan N, Babu M. Curcumin inhibition of bleomycin induced pulmonary fibrosis in rats. Br J Pharmacol. 2002;131(2):169-72. https:// doi.org/10.1038/sj.bjp.0703578 PMid:10991907 PMCid:PMC1572330.

19. Siddiqui AM, Cui $X$, Wu R, Dong W, Zhou M, Simms HH et al. The anti-inflammatory effect of curcumin in an experimental model of sepsis is mediated by up-regulation of peroxisome proliferatoractivated receptor-gamma. Crit Care Med. 2006;34(7):1874-82. https://doi.org/10.1097/01.CCM.0000221921.71300. BF PMid:16715036.

20. LoTempio MM, Veena MS, Steele HL, Ramamurthy B, Ramalingam TS, Cohen AN, et al. Curcumin suppresses growth of head and neck squamous cell carcinoma. Clin Cancer Res. 2005;11(19):6994-7002. https://doi.org/10.1158/10780432.CCR-05-0301 PMid:16203793.

21. Suzuki M, Nakamura T, lyoki S, Fujiwara A, Watanabe Y, Mohri K et al. Elucidation of anti-allergic activities of curcumin-related compounds with a special reference to their anti-oxidative activities. Biol. Pharm. Bull. 2005;28(8):1438-43 https://doi.org/10.1248/bpb.28.1438 PMid:16079489.

22. Reddy RC, Vatsala PG, Keshamouni VG, Padmanaban G, Rangarajan PN. Adv Eep Med Biol. 2005;595:105-25

23. Barry AL: Agar diffusion: general considerations. In: Barry AL (ed.) Theantimicrobic susceptibility test: principles and practices. Lea \& Febiger, Philadelphia, PA USA: 1979.p.163-179. PMid:513907.

24. Reiner R. 1982. Antibiotics: An Introduction. F Hoffmamm-La Roche and Co.Ltd. Switzerland, 21-27, Samy RP. Antimicrobial activity of some medicinal plants from India. Fitoterapia. 2005;76:697-99.

25. Singh AG, Kumar A, Tewari DD. An ethnobotanical survey of medicinal plants used in Terai forest of western Nepal. J Ethnobiol \& Ethnomed. 2012;8(19):2-14 https://doi.org/10.1186/1746-4269-8-19.

26. Rahman Md Saifu, Hasan KDB et al. Ethanol extract of Curcuma longa leaf, a potential drug candidate against Bacillus species mediated infections. Int. J Biosci. 2014;4(7):9-14.

27. Winee Surabhi Lall, Amit Alexander Charan, Akhilesh Bind. Antimicrobial activity of methanolic and acetonic Extracts of Azadirachta indica, Saraca asoca and Curcuma longa. Int J Med \& Pharm Scil. 2013;3(2):79-86.

28. Parastoo Karimi Alavijeh, Parisa Karimi Alavijeh, Devindra Sharma. A study of antimicrobial activity of few medicinal herbs" Asian J Plant Sci \& Res. 2012;2(4):496-502.

29. Singh RP, Jain DA. Evaluation of antimicrobial activity of curcuminoids isolated from turmeric. Int J Pharma\& Life sci. 2012;3(1):1368- 76.

30. Md. Nazmul Hasan, Aysha Ferdoushi, Nargis Ara, Shahnaz Rahman, Md. Shahadat Hossan, Md Rahmatullah. Preliminary Phytochemical Screening, Toxicity, Antihyperglycemic and Analgesic Activity Studies with Curcuma longa Leaves. World J Pharma \& Pharma Sci. 2014;3(9):81-91.

31. Gupta Ankur, Mahajan Surbhi, Sharma rajendra. Evaluation of Antimicrobial activity on Curcuma longa rhizome extract against staphylococcus aureus. Biotechnology reports. 2015;6:51-55. https://doi.org/10.1016/j.btre.2015.02.001

32. GA Cordell, Quinn-Beattie MN \& Farnsworth NR. The potential of alkaloids in drug discovery. Photother Res. 2001;15(3): 183-205. https://doi.org/10.1002/ ptr.890 PMid:11351353.

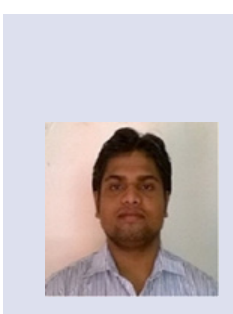

\section{ABOUT AUTHORS}

Nikhil Singh: Presently working as an Assistant Professor in a reputed Institution METGI, Faculty of pharmacy, Department of Pharmacology, Moradabad. Pursued D. pharm from Delhi University as well as B. pharm \& M. pharm from R.U.H.S, Jaipur and NIPER, Hajipur. He has scored excellence in various entrance exam such as GPAT (2013), GATE, life sciences (2013, IIT), NIPER JEE (2013), GPAT (2014) and GPAT (2015). Having 2 years of teaching experience and he has guided 07 undergraduate project. He has published various research article in National and International journals \& attended various seminars and Conferences. He has research background in the case study of the hypertension under the guidance of Dr. Shridhar Dwivedi (Dean of HIMSR, Jamia Hamdard, New Delhi). 


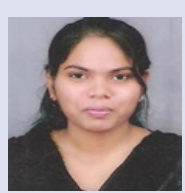

Sangeeta Gupta: Currently working as an Assistant Professor in Moradabad group of Institution, Faculty of Pharmacy in Pharmacognosy Department, Moradabad. Pursued B. pharm and M. pharm from reputed Institute with Honors. Has 4 years of teaching experience and 1 year Industrial experience. Had worked as a trainee in National Dope Testing Laboratory, New Delhi and guided various undergraduate students in their projects. She had published various articles in National and International journals and attended various seminars and Conferences.

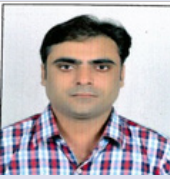

Vaibhav Rathore: Presently working as an Assistant Professor in Moradabad group of Institution, Faculty of Pharmacy in Pharmaceutics Department, Moradabad. Pursued B.pharm and M.pharm from IFTM and Teerthankar Mahaveer University, Moradabad by scoring 2nd position in Post graduation. Has more than 5 years of teaching experience and also worked as a Research Executive in Indian Drug and Pharmaceutical Ltd, Gurgaon. His area of expertise and interest is in Formulation \& Development of Pharmaceutical products. He has also published various articles in National and International journals and attended various seminars and Conferences.

Cite this Article: Singh N, Sangeeta G, Rathore V. Comparative Antimicrobial Study of Ethanolic Extract of Leaf and Rhizome of Curcuma longa Linn. Pharmacogn J. 2017;9(2): 208-12. 